\title{
The Effect of Modification by Strontium of the AlSi7Mg0.3 Alloy on the Surface Roughness
}

Nataša Náprstková, Jaromír Cais, Jaroslava Svobodová.

Faculty of Production Technology and Management, JEPU in Ústí nad Labem. E-mail: naprstkova@ fvtm.ujep.cz

Al-Si Alloys are a leading casting alloys based on aluminum. Machining of aluminum alloys is currently frequently used and it is an important area of production. The paper deals with an experiment, that was realized at the Faculty of Production Technology and Management, University of Jan Evangelista Purkyne in Ústí nad Labem, where was machined alloy AlSi7Mg0.3. Samples were made for machining because of the master alloys of AlSi7Mg0.3, where part of the castings was left in its original condition and part of the castings was modified by strontium. This paper describes the evaluation of surface roughness obtained after machining of these castings in terms of how the modification by strontium can affect this.

Keywords: modification, surface roughness, silumin, machining

\section{References}

[1] BILÍK, O. Obrábění I- 1. díl. Ostrava: VŠB-TU Ostrava, 2001. 136 s. ISBN 80-7078-811-9.

[2] MICHNA, Š., LUKÁČ, I., OČENÁČEK, V., KOŘENÝ, R., DRÁPALA, J., SCHNEIDER, H., MIŠKUFOVÁ, A. a kol. Encyklopedie hliníku. Adin, Prešov, 2005, ISBN 80-89041-88-4.

[3] MICHNA, Š., KUŚMIERCZAK, S. Technologie a zpracování hliníkových materiálů. UJEP. Ústí nad Labem, 2008. $152 \mathrm{p}$

[4] BOLIBRUCHOVÁ, D., TILLOVÁ, E. Zlievarenské zliatiny Al-Si. ŽU, Žilina: EDIS - vydavatelstvo ŽU, 2005. ISBN 80-8070-485-6

[5] ČSN EN 1796 - Hliník a slitiny hliníku - Odlitky - Chemické složení a mechanické vlastnosti

[6] ČAPEK, J. Analýza vlivu titanu na opotřebení nástroje při obrábění hliníkových slitin., Bacelor thesis, FVTM UJEP. 2011

[7] ČSN EN ISO 4287 Geometrické požadavky na výrobky (GPS) - Struktura povrchu: Profilová metoda - Termíny, definice a parametry struktury povrchu

[8] MiCHNA, Š. NAPRSTKOVÁ, N. The Mechanical Properties Optimizing of of Al - Si Alloys Precipitation Hardening and the Effect on the Character of the Chip, Acta Metallurgica Slovaca, 3/2011, ISSN-1335-1532

[9] MÁDL. J., HOLEŠOVSKÝ, F. Integrita obrobených povrchů z hlediska funkčních vlastností. 1.vyd. Ustí nad Labem, FVTM UJEP, 2008, 230 pp. ISBN 978-80-7414-098-2

[10] KALINCOVÁ, D. Skúšanie mechanických vlastností materiálov - prehl’ad meracích metód a zariadení. In Zvyšovanie efektívnosti vzdelávacieho procesu prostredníctvom inovačných prostriedkov. KEGA 3/6370/08., TU vo Zvolene, Zvolen. 2010, pp. 13-26.

[11] MADL, J. Surface Properties in Precise and Hard Machining, Manufacturing Technology, Vol. 12, 2012, pp. 158-166. ISSN 1213-2489

[12] NOVAK M. Surface quality of hardened steels after grinding. Manufacturing Technology, Vol. 11, pp. 55-59, ISBN 1213-2489

[13] NOVAK, M. Surfaces with high precision of roughness after grinding. Manufacturing Technology, vol. 12, 2012, pp. 66-70, ISSN 1213-2489

[14] VALÍČEK, J., RUSNÁK, J., MÜLLER, M., HRABĚ, P., KADNÁR, M., HLOCH, S., KUŠNEROVÁ, M. Geometrické aspekty drsnosti povrchu klasických a netradičních technologií. Jemná mechanika a optika, 2008, Vol. 53, No 9, pp. 249-253. ISSN 0447-6441.

[15] NOVÁK, M., HOLEŠOVSKÝ, F. 2009. Problematika broušení hliníkových slitin. Transactions of the Universities of Košice, No.4, 2009, Košice, pp. 284-291. ISSN1335-2334

[16] CZÁN, A., STANČEKOVÁ, D., ĎURECH, L., ŠTEKLÁČ, D., MARTIKÁŇ, J. Základy opotrebenia pri suchom tvrdom sústružení. Nástroje 2006 - ITC 2006, 5. - 6. september 2006, Zlín 